Research Article

Volkan Okur*

\title{
GIS based approach to analyze soil liquefaction and amplification: A case study in Eskisehir, Turkey
}

https://doi.org/10.1515/geo-2018-0067

Received Jul 18, 2018; accepted Oct 24, 2018

\begin{abstract}
This study involves gathering the geological and geotechnical data and processing them in 3D structural model for the assessment of the likelihood of liquefaction hazard. A total of 467 borehole logs up to $30 \mathrm{~m}$ of depth were analyzed. Based on engineering characteristics of the soil formation, Geographical Information System based subsurface model maps and liquefaction hazard maps were prepared. Also microtremor measurements have been taken on different locations to assess the amplification of the alluvial formation. By obtaining amplification spectrum between the soil layers and response spectra at the top of the bedrock and at ground surface, a thematic map on amplification factor is produced. It is believed such kind of visual models will help engineers and designers on all aspects of future development of the cities especially transportation, infrastructure, and land uses against possible earthquake hazards.
\end{abstract}

Keywords: Earthquake hazard mitigation, Voxel Analyst, Geographic Information System, Liquefaction, Soil Amplification

\section{Introduction}

Structural failures during seismic events are mostly attributed to insufficient or incorrect site investigations. To minimize the risk in the computations, a number of geological and geotechnical investigations may be needed [1]. However, several studies have shown that in most cases geotechnical investigations are inadequate as very few resources are committed to the investigation. Geotechnical investigation expenses vary significantly between $0.025 \%$

\footnotetext{
^Corresponding Author: Volkan Okur: Department of Civil Engineering, Eskisehir Osmangazi University, 26480, Eskisehir, Turkey; Email: vokur@ogu.edu.tr
}

and $0.3 \%$ of the total project cost. Inadequate data on soil properties result in large uncertainties, and large uncertainties result in large construction costs for unknown conditions $[2,18]$.

Various instrumental field observations have been obtained during recent earthquakes, reflecting the effects of geotechnical site conditions. During earthquakes, soil layers are subjected to multidirectional cyclic stresses with different amplitudes and frequencies that lead to cyclic deformations and changes in stress-strain and strength properties. Earthquake characteristics on the ground surface are mostly affected by the soil layer properties. Numerous strong motion records obtained within relatively short distances from each other have shown that ground motion characteristics differ significantly between nearby locations due to differences in the interactions between the earthquake source, its path and the geological site conditions. Thus, modeling the ground conditions appropriately can control for vulnerability during a seismic event [3].

There have been a number of studies assessing the deterministic and probabilistic seismic hazard risks for the city of Eskisehir of Turkey [4]. An investigation on the hydrogeological and seismotectonic features has been performed and the liquefaction potential map is prepared for the city center of Eskisehir by [5]. To estimate the vulnerability of the building stock, the average acceleration response spectra obtained from site response analyses was used to determine the spectral accelerations for short $(0.2 \mathrm{~s})$ and long $(1 \mathrm{~s})$ periods. In addition, the risks posed by future seismic events in the area of concern using a probabilistic seismic loss estimation methodology with 13 main and 4 background source zones were evaluated. It's found that peak ground acceleration and MSK intensity were 0.26 $\mathrm{g}$ and 7.5 , respectively, with a $10 \%$ probability of $50 \mathrm{ex}-$ ceedance over 50 years [6].

Geographical Information System (GIS) is a tool that is widely used to plan the proper management of all geographically referenced information [7]. With the development of GIS engineering tools, it is possible to integrate and compare any data with spatial components, re- 


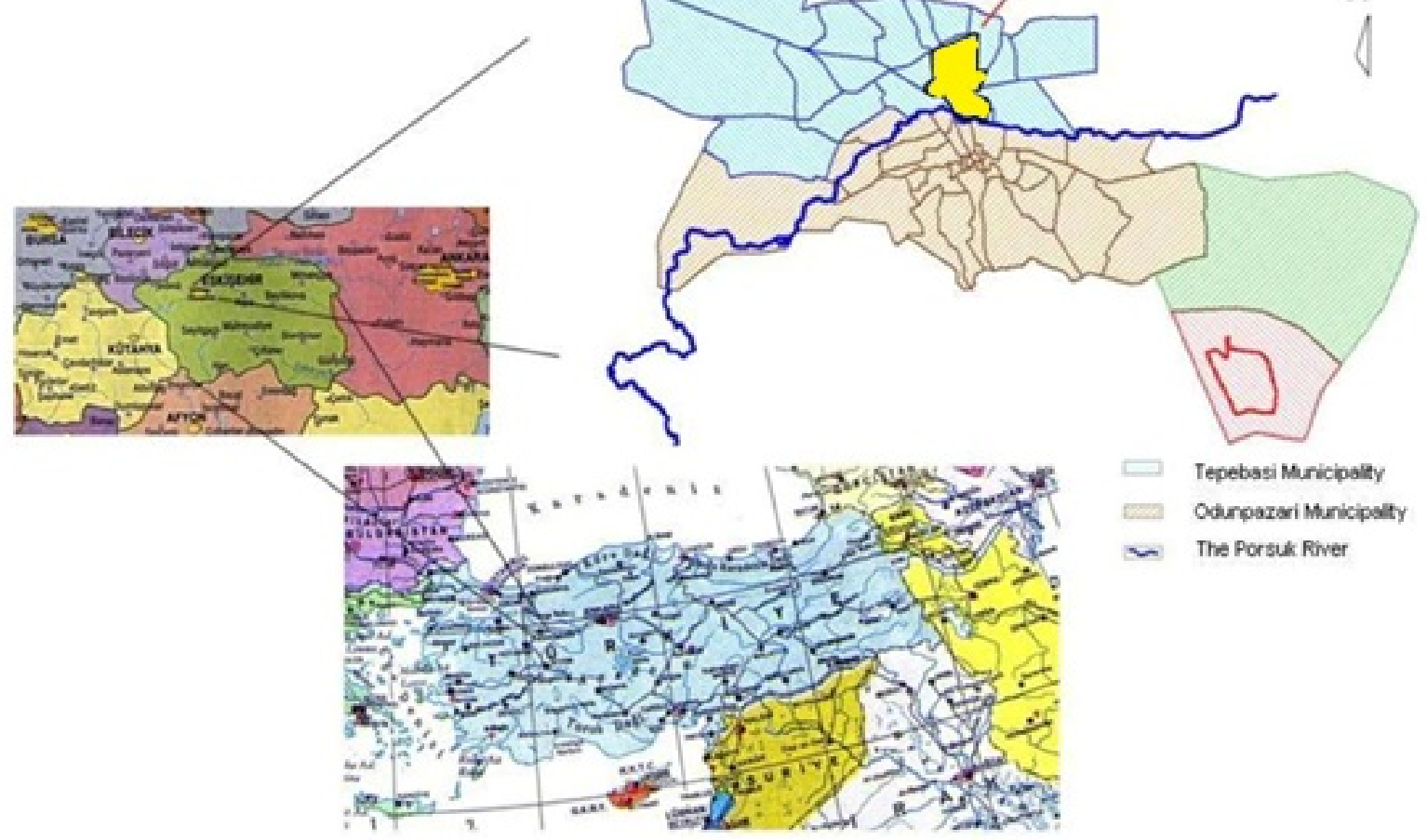

Figure 1: Location of the study area.

gardless of the data's source [8]. Previous studies have attempted to propose 3D models to characterize the site response of various basins $[9,10]$. The aim of the present study was to assess liquefaction susceptibility of the city of Eskisehir, which is located on alluvial deposits, in conjunction with amplification phenomena and to develop 2D and 3D model of the sedimentary sequence using GIS methodology. The proposed 3D model describes the geometry and dynamic characteristics of the basin. Ultimately, the findings should provide data for further urban planning studies for the city.

\section{Methodology}

\subsection{Geological setting}

We selected a study zone that covered a number of populated districts in the city of Eskisehir, which is located in midwestern Turkey (Figure 1). The Porsuk River divides the city into two parts, and the study area (shaded in yellow in Figure 1) is located in the north of the river. The city's topographic and municipal borders are shown as yellow lines in Figure 2. The city's altitude ranges from 790-1,010 $\mathrm{m}$; the Porsuk River has an average altitude of $795 \mathrm{~m}$, and the city's highest altitude $(1,010 \mathrm{~m})$ is in its northern and northwestern areas.

The geology is formed of loose sedimentary rocks 70 scattered across the plain. The basin's basement consists of Mesozoic gabbro and marble, Eocene and Miocene conglomerates, sandstone conglomerate, claystone marn and limestone. Both younger and older alluvial sequences cover large areas, describing the Quaternary deposits. Pleistocene conglomerates, sands and gravels intercalated with mudstone and caliches have a maximum exposed thickness of about $200 \mathrm{~m}$, and overlie the Miocene and preNeocene formations. Uppermost Pleistocene sediments are overlain by $10-90 \mathrm{~m}$ thick Holocene alluvium that is comprised of the loose sand and gravel of the Porsuk River [11]. These materials are composed of mixtures of Eocene conglomerates, consisting of gravels embedded in clay soil, and behave like a stiff soil. The upper part of the basin was deposited on a weathered soft Miocene, with the exception of the limestone, which is rather silicified. The old alluvium sequence crops out at a high topographic scarp of the plain; when compared to the young alluvium, 


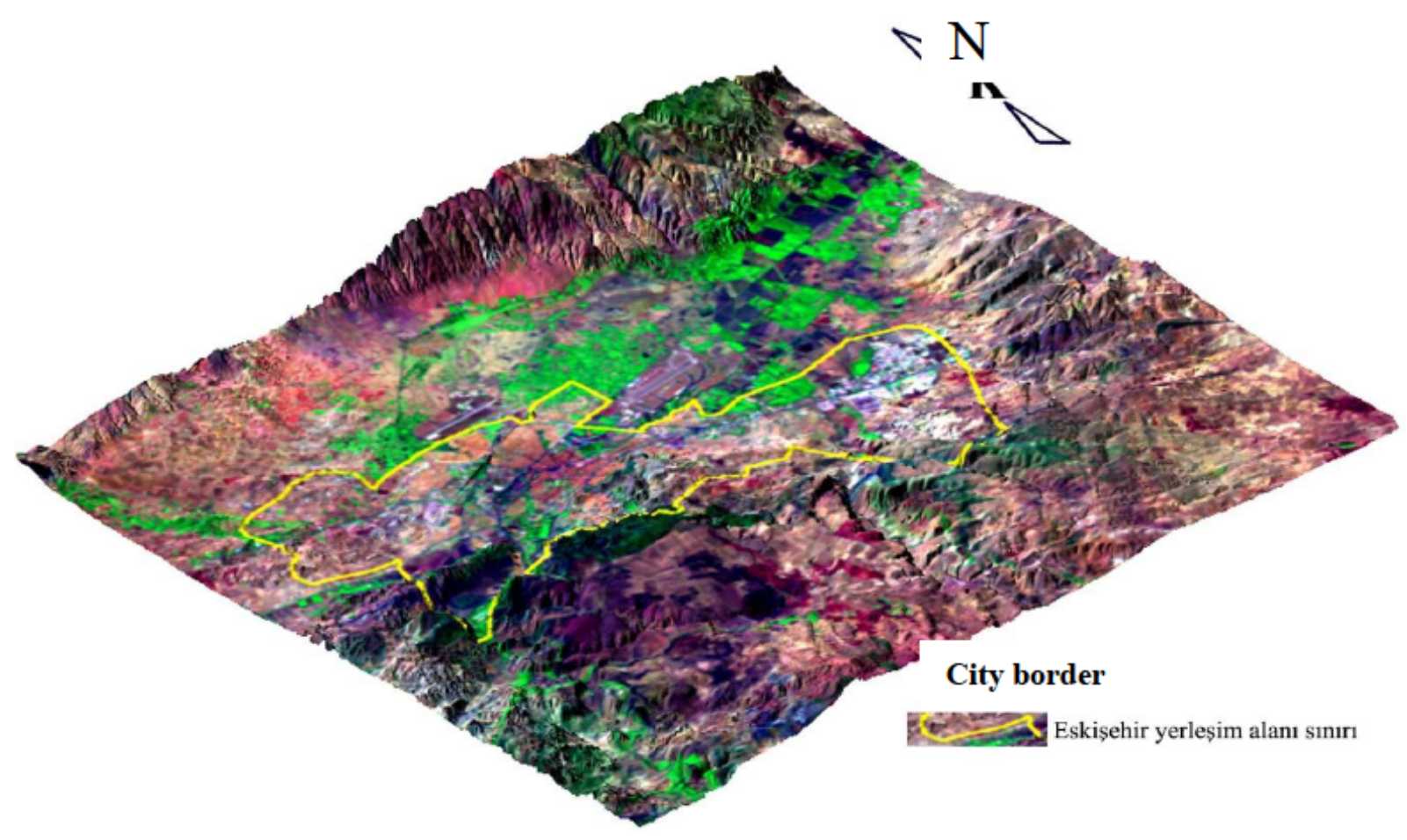

Figure 2: Topographic map of city of Eskisehir.

it is significantly stiffer and seldom involves carbonatecemented conglomerate layers. The more recent alluvium generally consists of loose sediments and its thickness ranges from $30-40 \mathrm{~m}$ at the basin margins and extends up to $90 \mathrm{~m}$ toward the center of the basin. Generally, sand containing higher amounts of silt formation is located in the upper layers, between 5-10 m. Sand, including sand containing silt layers, can be encountered as far the lower layers. The fraction of sand increases toward the lower levels, where a gravelly sand layer begins to form [12].

The Inonu, Eskisehir and Alpu basins are confined by faults in the south and north of the study area, which consists of alluvial plains with a total surface area of $639 \mathrm{~km}^{2}$ (Figure 3). Two main oblique faults exist throughout the city. The main tectonic fault system of basin trends NW-SE and exhibits normal faulting characteristics with slight lateral components. They form the Eskisehir plain and have inclinations between $60^{\circ}$ and $80^{\circ}$. The Eskisehir-Inonu Fault Zone (EIFZ) is the most important fault zone. It is divided into branches and extends as a zone $1-4 \mathrm{~km}$ wide, running toward the north. According to current knowledge of the morphological evidence, the position of the ophiolitic rocks and the distribution of the earthquake epicenters, this fault can be classified as an active fault and is assumed to be the seismic source for future earthquakes in the city of Eskisehir [13].
Even though the activity of the faults surrounding the Eskisehir plain is limited and some of its parts are buried by unconsolidated Miocene formations, it is possible that there exists a restricted extensional regime by the NESW striking dominant tectonic effect. Prior to the Neotectonic period, the NW-SE trending dextral strike-slip system was transformed into an extensional regime by the effects of the North Anatolian Fault Zone during the PlioQuaternary; it has been stated that this buried fault acted as a pure strike-slip fault before the Neotectonic period.

\subsection{Approach used}

We used Voxel Analyst (VA) software for 2D and 3D analysis of the gathered data. VA is specifically designed for volume modeling, analysis of spatial relationships with heterogeneous data volumes, and visualization [14]. It provides tools for loading, modeling, analyzing, manipulating and plotting 3D scientific data. Data can be imported from external 2D and 3D modeling packages in standard ASCII format, and sparse data can be loaded and numerically modeled using several algorithms. Graphic components such as cross-sections, cutting planes, chair displays, isosurfaces and isosolids can be generated and edited interactively. VA's multithreading capability allows for graphic displays and computations to be done simultaneously. VA 


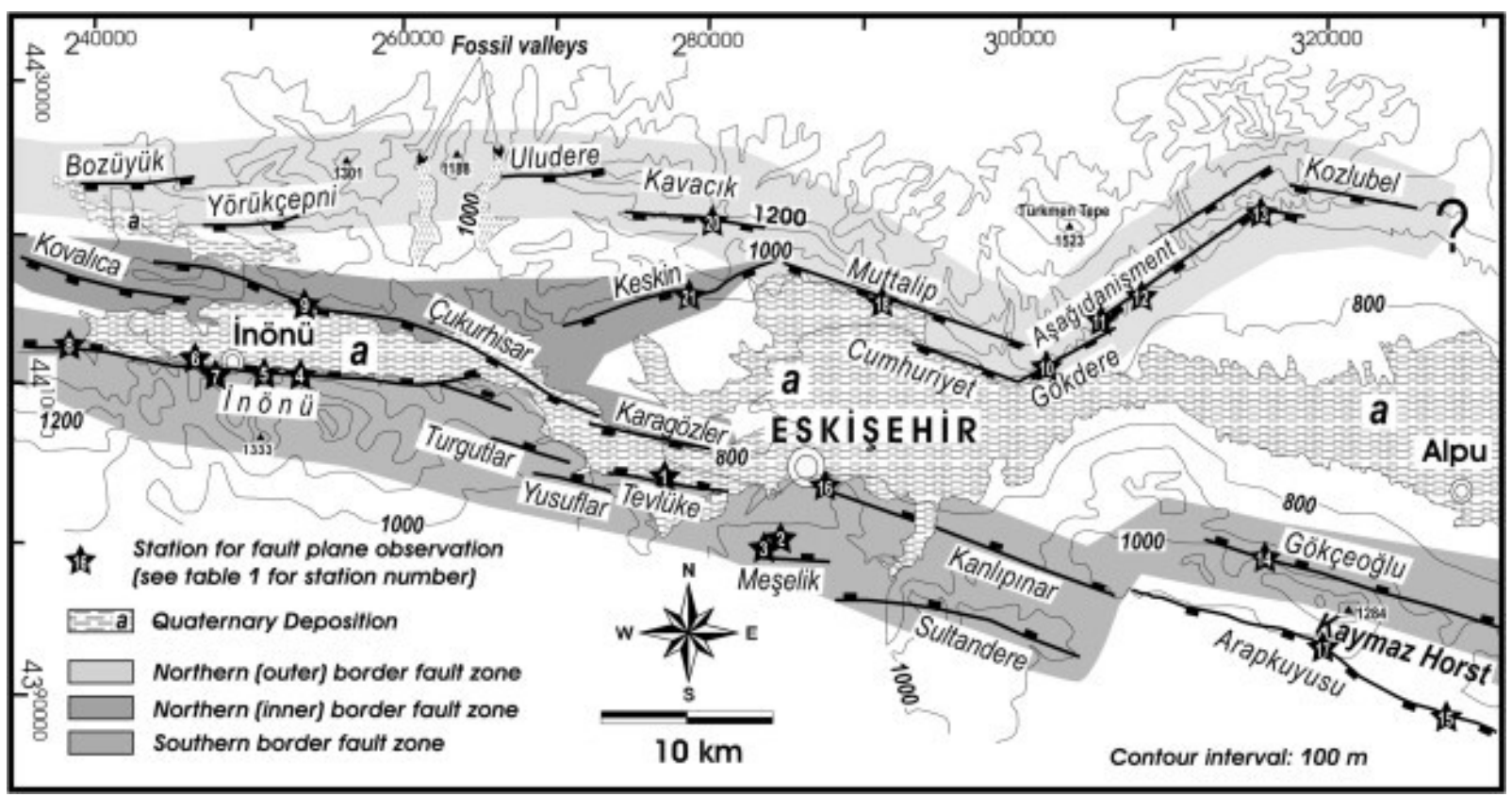

Figure 3: Fault segments in the Eskişehir Fault Zone (Altunel and Barka 1998).

runs as a stand-alone program and it can also import or export data in AutoCAD. VA has geological and geotechnical engineering modeling and analysis capabilities, and more specifically it can evaluate alluvial deposits (gravel, sand, silt and clay). It is 115 also possible to create 3D distributions and calculate the volume of the deposits. The area of the pilot zone is approximately $5.2 \mathrm{~km}^{2}$ and covers 18 districts (Figure 4).

\section{Results and discussions}

\subsection{Geological and geotechnical investigation}

We split the $5.2 \mathrm{~km}^{2}$ study area into 537 grid cells (Figure 5) for the ground modeling; each cell had an area of $0.10 \mathrm{~km}^{2}$ $(100 \times 100 \mathrm{~m})$. Based on a detailed assessment of available geotechnical data, including a total of 467 borehole logs up to $30 \mathrm{~m}$ deep, we created representative soil profiles for each cell where one or more borehole data were available, using the most appropriate borehole for each cell. Standard penetration tests (SPT) were performed for every $1.5 \mathrm{~m}$. throughout the entire length of each bore hole [19]. For cells with no borehole data present, we estimated their soil profiles based on those of its neighboring cells by using the inverse distance interpolation method. The ground's top layers, up to a depth of 4-5 m, consisted of fine-grained soils that can be classified as low plasticity clay-silt, CL-ML according to the unified soil classification system. The sandy layer after this stratum consisted of finegrained silt grading to coarse-grained sand and gravel in the lower part of the section. The sandy part can be classified as silty sand, SM, where the coefficient of uniformity $\left(C_{u}\right)$ ranged from 4-8, and mean particle diameter $\left(D_{50}\right)$ was $0.06-0.5 \mathrm{~mm}$. The thickness of this soil profile ranged from $3-15 \mathrm{~m}$. The depth of the groundwater fluctuated between $3-5 \mathrm{~m}$. The groundwater level is taken $3 \mathrm{~m}$. for the computations (Figure 6).

We performed one-dimensional seismic ground response analysis using "Shake 2000" software to determine the elastic acceleration response spectra on the ground surface [25]. Correlation by [15] was used to correlate the standard penetration resistance with shear wave velocity as:

$$
V_{S}=51.5 N^{0.516}
$$

where $N$ represents the uncorrected standard penetration blow counts. We established shear wave velocity values down to the engineering bedrock, with an estimated shear wave velocity of $760 \mathrm{~m} / \mathrm{s}$. We also determined that equivalent shear wave velocities for the topmost $30 \mathrm{~m}$ ranged from $160-450 \mathrm{~m} / \mathrm{s}$. We then compared these calculated shear wave velocity profiles to shear wave velocity data from microtremor array results and modified our profiles if necessary. Representative soil profiles are shown in Figure 6. For each soil layer in the soil profiles, we calculated the total unit weight and shear wave velocity. For 


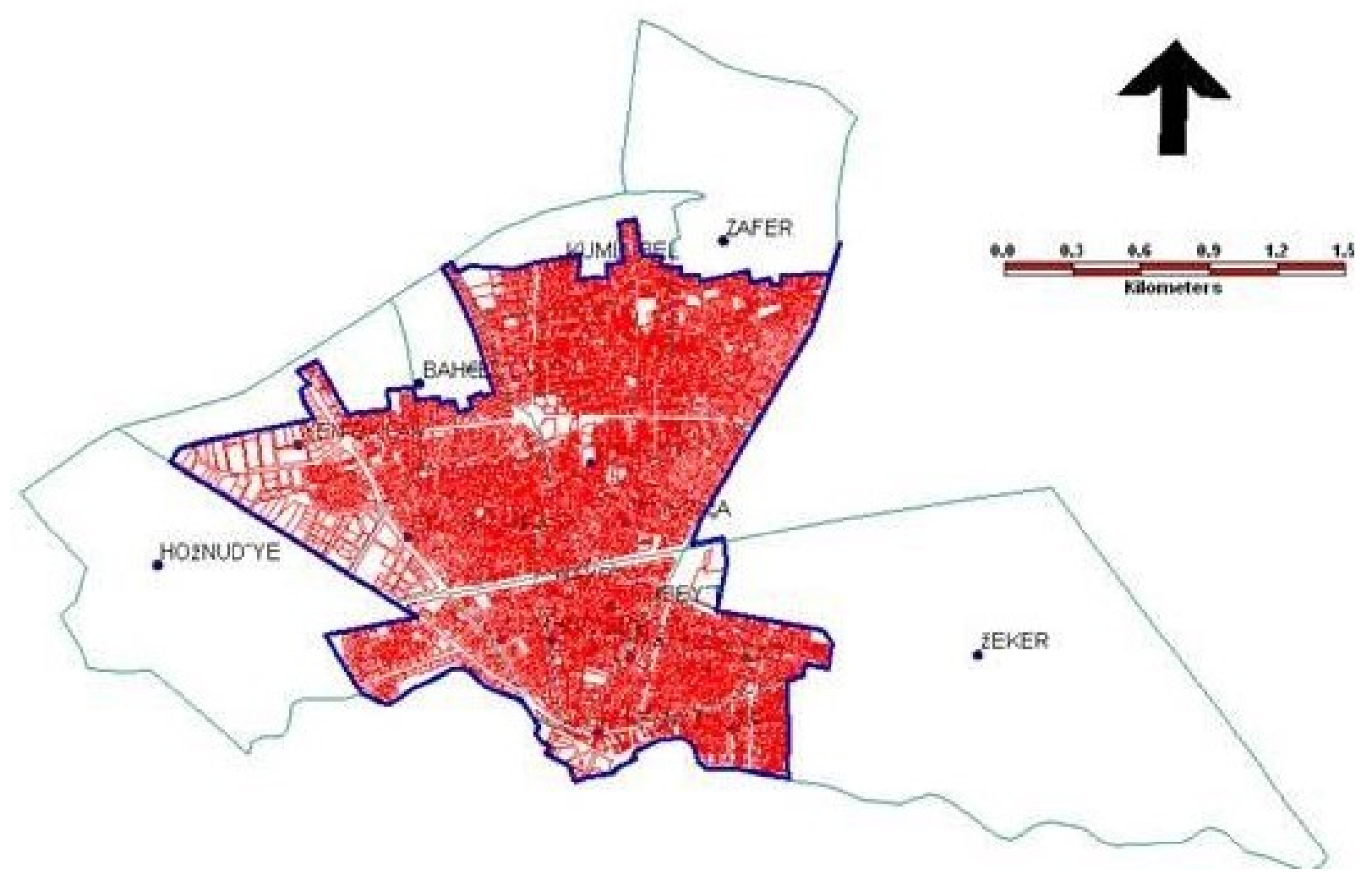

Figure 4: Study area.

Table 1: List of earthquake accelerations used in the study.

\begin{tabular}{ccccc}
\hline Earthquake & Station & Magnitude & Component & $\begin{array}{c}\text { PGA } \\
\text { (g) }\end{array}$ \\
\hline $\begin{array}{c}\text { Duzce } \\
11 / 12 / 99 \\
\text { Kocaeli } \\
17 / 09 / 99\end{array}$ & 531Lamont & 7.1 & 1059E & 0.133 \\
\hline
\end{tabular}

all types of soil, we used the generic $\mathrm{G} / \mathrm{G}_{\max }$ and damping curves proposed by [24]. For input motion 1999 Kocaeli and 1999 Duzce earthquake databases were used (Figure 7). The recorded PGA values are given in Table 1. We used these for the rock outcrop motion inputs and scaled the acceleration time history inputs for all cells with respect to the peak accelerations obtained by [20-22].

An assessment of the conditions that will trigger liquefaction is one of the most important steps in any seismic risk project. Over the years, different approaches have been developed to evaluate the liquefaction potential of soil deposits, such as the stress-strain or energy-based methods. Most of these assessment methods were developed based on laboratory and in-situ tests. One of the most popular techniques is a deterministic method termed the "cyclic stress method" or "simplified procedure;" this calculates both seismic loading and soil liquefaction resistance in terms of cyclic stress. It is a procedure developed by [16] after the devastating 1964 earthquakes in Alaska and Niigata, Japan, uses empirical estimations of filed observations and laboratory investigations. This method compares seismic induced loading, defined in terms of cyclic shear stress, to the liquefaction resistance (cyclic resistance ratio) of the soil. A safety factor of $<1$ indicates that potential demand exceeds resistance and that liquefaction is expected to be triggered. This procedure has since been modified and is now a widely accepted method for estimating liquefaction risk [17]. In this study SPT based method was used.

\subsection{Liquefaction analysis and mapping}

The liquefaction potential index $\left(\mathrm{P}_{L}\right)$ is a weighted integration of the liquefaction resistance safety factor within the uppermost $30 \mathrm{~m}$ of sediment beneath the site [26, 27]. This method is especially well suited for GIS applications used to evaluate the probability of liquefaction at a given site. The method estimates liquefaction susceptibility based on the penetration resistance of SPT depth measurements, 


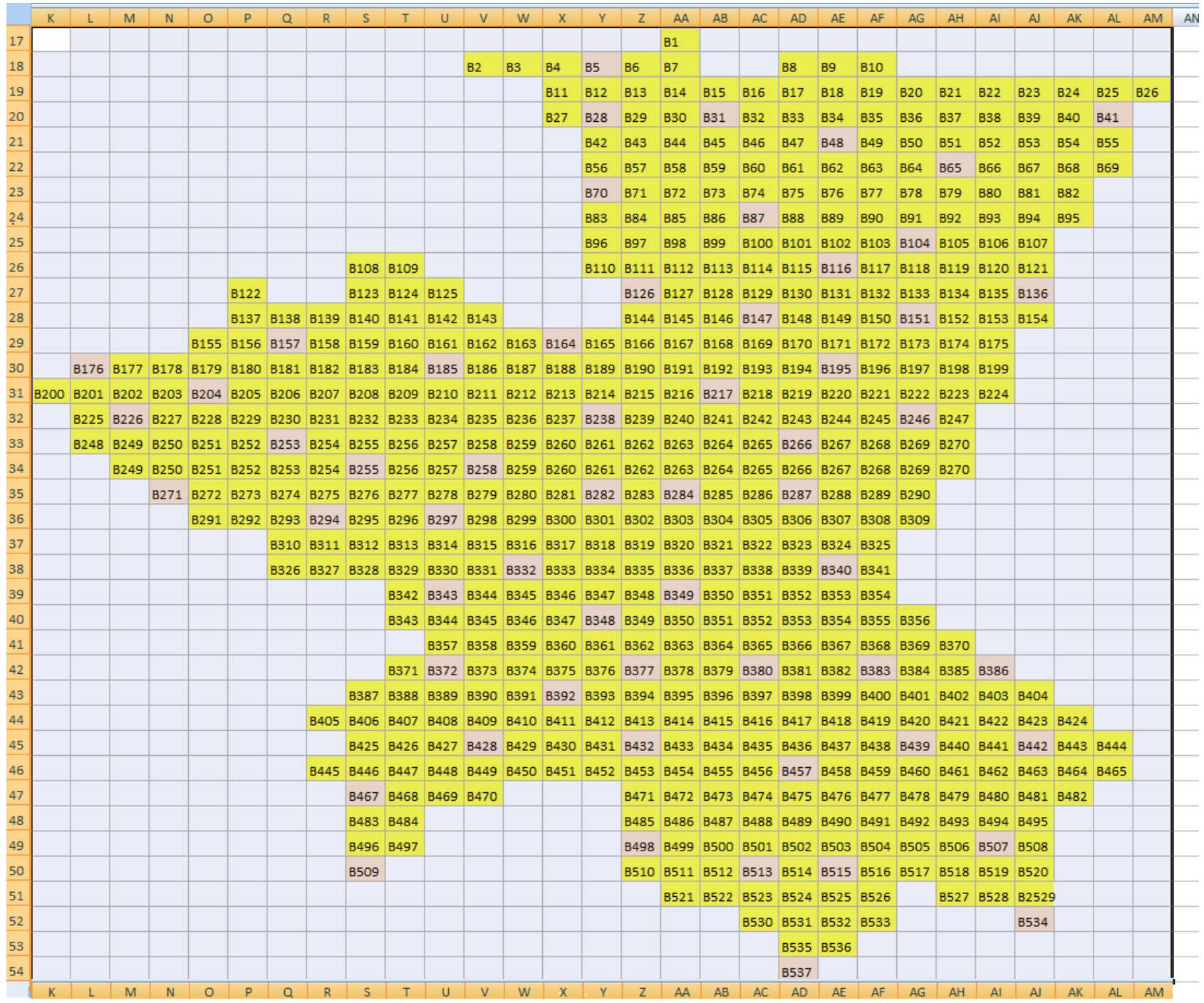

Figure 5: Cell locations and borings. The pink colured cells indicates that the data for this boring selected from neigbouring cells. The yellow colour cells shows the boring is located in the same cell.

and determines the index related to that site on the ground surface. The calculations was based on the procedure formerly proposed by [28] using the variation of the safety factors with depth. The liquefaction potential index, $P_{L}$, defined as

$$
P_{L}=\int F(z) w(z) d z
$$

where $z$ is the below the ground water surface, measured in meters; $F(z)$ is a function of the liquefaction resistance factor, $F_{L}$, where $F(z)=1-F_{L}$ but if $F_{L}>1.0, F(z)=0$; and $w(z)=10-0.5 z$. Eq. (2) gives values of $P_{L}$ ranging from 0 to $100 . F_{L}$ is the factor of safety against liquefaction.

The liquefaction susceptibility criteria based on liquefaction potential index is presented in Table 2 . The site may then be spatially located by determining the geographic coordinates, and together with all of the boring informa- tion, the $P_{L}$ then becomes an additional feature connected to the spatial element. The index value characterizes the site at the ground surface since the weighting function used by the $P_{L}$ has its maximum value at the ground surface, giving more weight to $\left(1-F_{L}\right)$ values at shallow depths.

We mapped the distribution of the likelihood of liquefaction at any given location in the form of $P_{L}$ contours, which we produced using the results of the SPT measurements as discrete values. These $P_{L}$ contours thus divide areas that are anticipated to experience different degrees of liquefaction. In addition, once a $P_{L}$ contour map is generated, other useful GIS-based spatial analysis operations may be performed, such as overlays with other GIS coverage containing the geospatial locations and attribute 

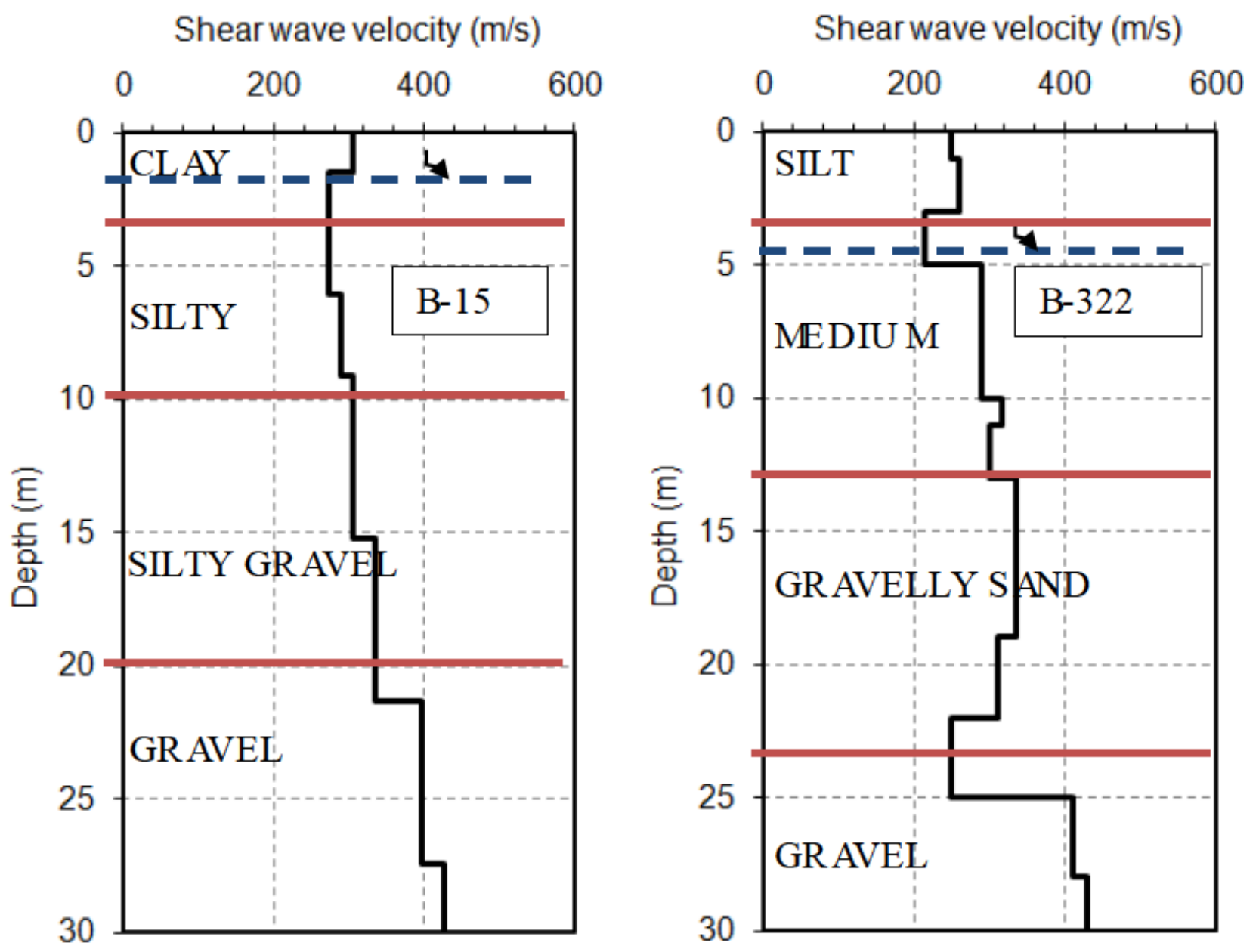

Figure 6: Variation of soil profile and shear wave velocity.

Table 2: Liquefaction susceptibility classification developed by [28].

\begin{tabular}{cc}
\hline $\begin{array}{c}\text { Liqufaction potential index } \\
\left(\mathrm{I}_{L}\right)\end{array}$ & Susceptibility \\
\hline $\mathrm{I}_{L}=0$ & Very low \\
$0<\mathrm{I}_{L} \leq 5$ & Low \\
$5<\mathrm{I}_{L} \leq 15$ & High \\
$15<\mathrm{I}_{L}$ & Very high \\
\hline
\end{tabular}

databases of civil engineering facilities, lifelines or populations at risk [23].

We performed the liquefaction susceptibility assessment for the uppermost $30 \mathrm{~m}$ of submerged silty sand and sandy sediments. We found that the existence of a shallow groundwater table in the alluvial layers along with shallow-seated silty sand levels showed a high potential for liquefaction. Our analyses also revealed that some parts of the study area close to the Porsuk River on the west were sensitive to liquefaction. In the case of a peak ground acceleration close to $a_{\max }=0.40 \mathrm{~g}$, a much larger area would also be affected by liquefaction.

We evaluated the amplification factor (i.e., the ratio of the peak horizontal acceleration at the ground surface to the peak horizontal acceleration at the bedrock) for each borehole. Microtremor array measurements conducted at six different points had different soil profiles, ranging from soft soil to soft rock. Figure 8 shows that the peak horizontal acceleration (PGA) values at the bedrock level were amplified at various locations; the amplification factors ranged from 2.5-4 and the spectral accelerations at $0.1 \mathrm{~s}$ ranged from $0.49-0.51$. We then divided the study area into three zones based on the liquefaction susceptibility and range of amplification 209 factors assigned to each zone.

Figure 9 shows the liquefaction potential index parameters for predicting the occurrence of liquefaction in a 2D map. Figure 10 shows the liquefaction-prone zones, as evaluated using a the safety factor method in a 3D map. Because the degree of damage due to liquefaction is significantly affected by the severity of liquefaction at differ- 

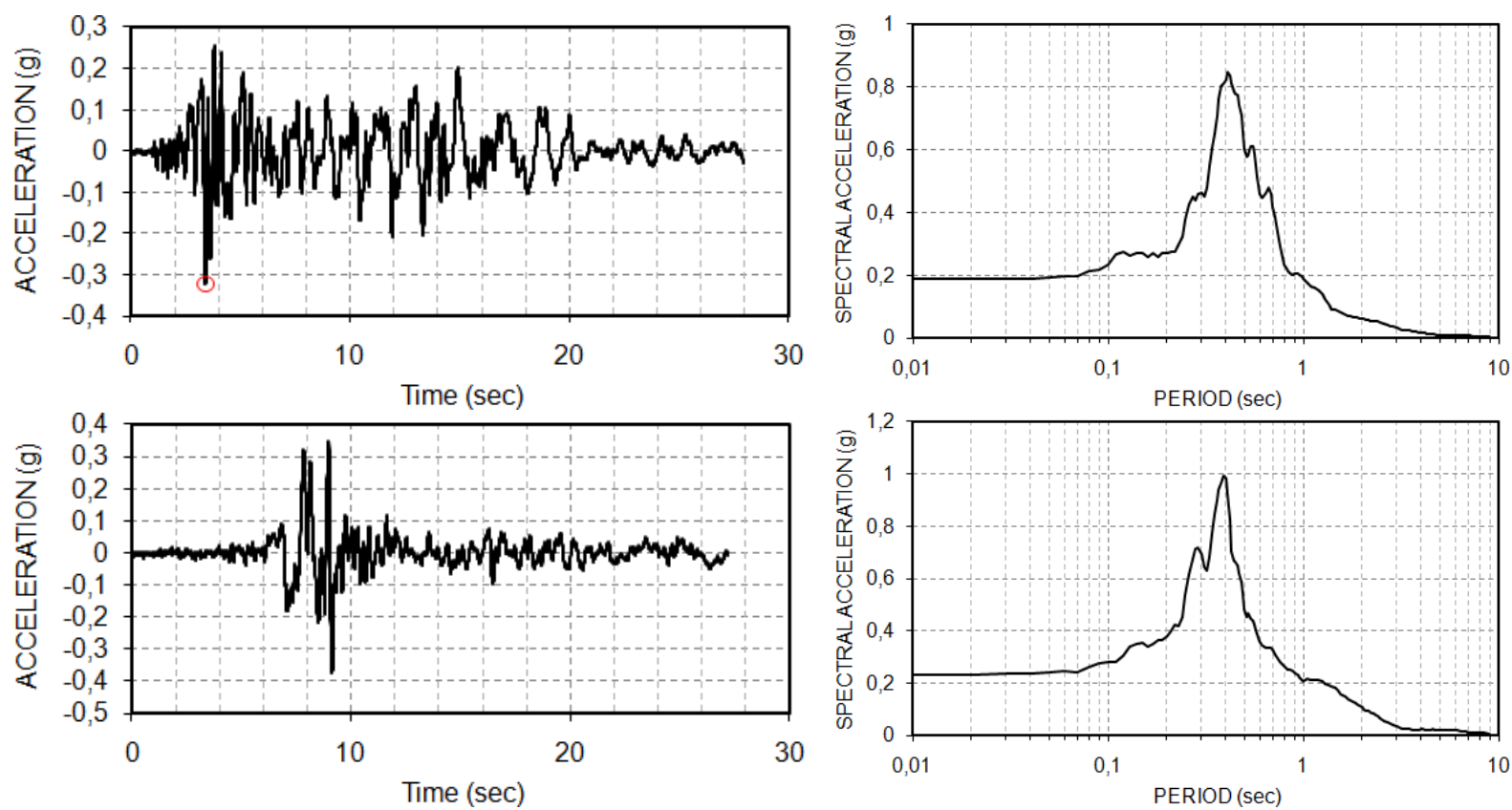

Figure 7: Acceleration time histories and their respective acceleration response spectra used as input motion in the site response analysis.

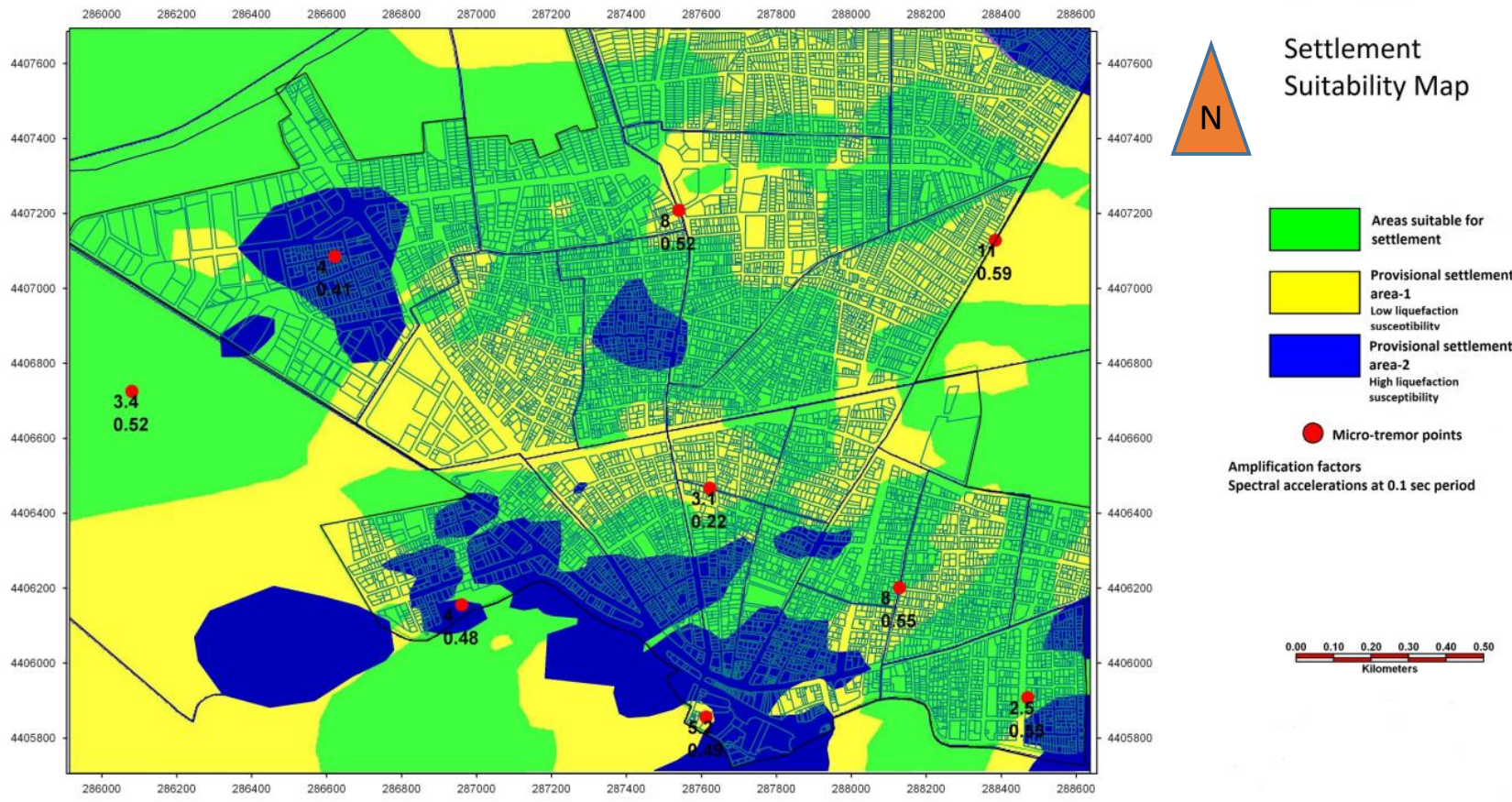

Figure 8: Settlement suitability map and amplification factors.

ent soil layers, the liquefaction potential index (which is proportional to the thickness and depth of the liquefiable layer), along with the safety factor, provide an estimate of the continuous volume of liquefiable soil deposit and an estimate of the interpolation confidence. The grids selected showed very low to very high degrees of liquefaction susceptibility in the city of Eskisehir. Zones with a high liquefaction susceptibility were found in some northern and western parts of the studied area. However, the 3D map makes it is easy to see the depth and thickness of the liquefiable layers. By identifying the thickness of the potentially liquefiable layer, it is thus easy to anticipate the liquefaction-induced settlement on the ground surface. This 3D information visualization data can help de- 


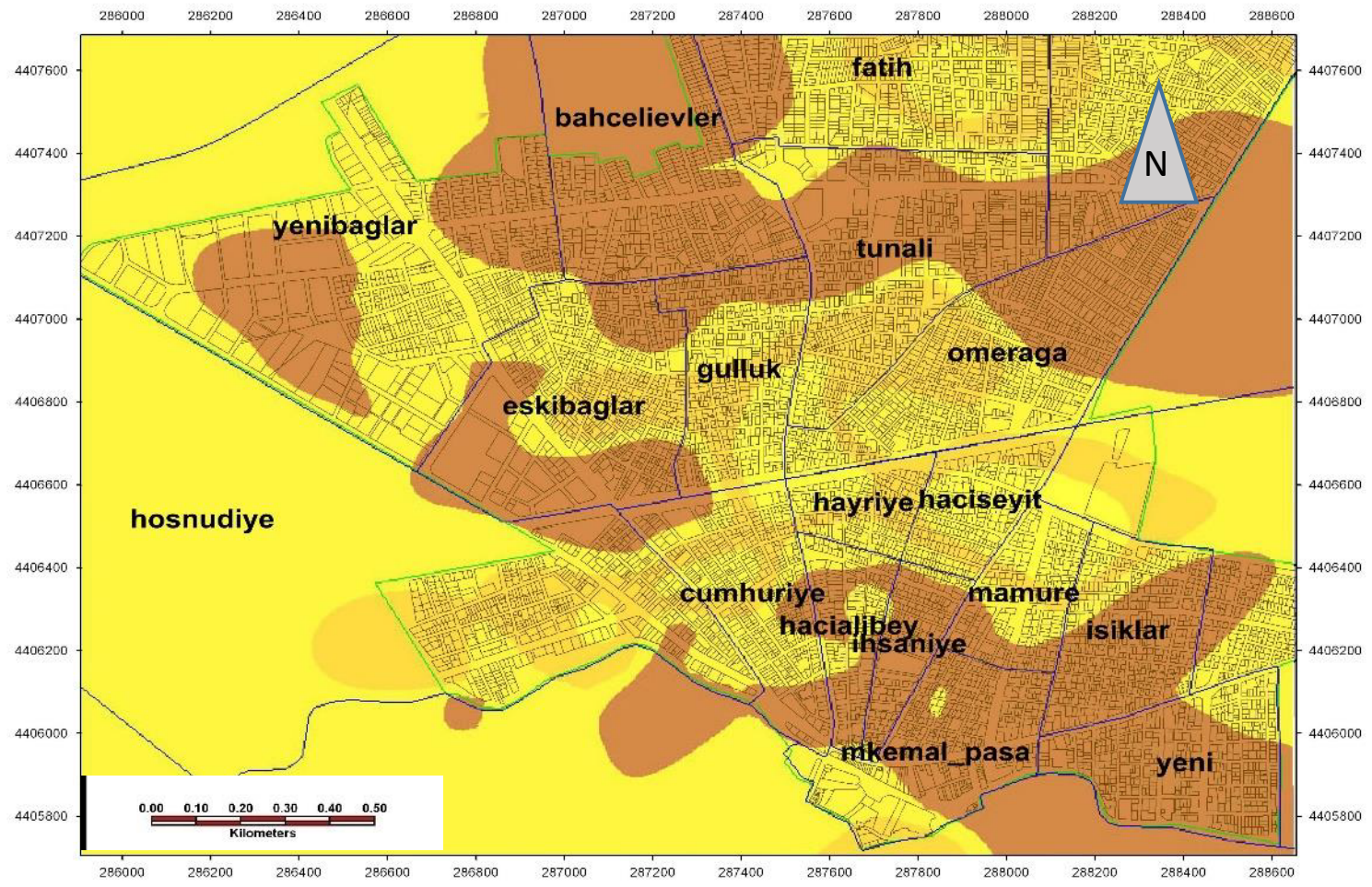

Figure 9: 2D Liquefaction susceptibility map.

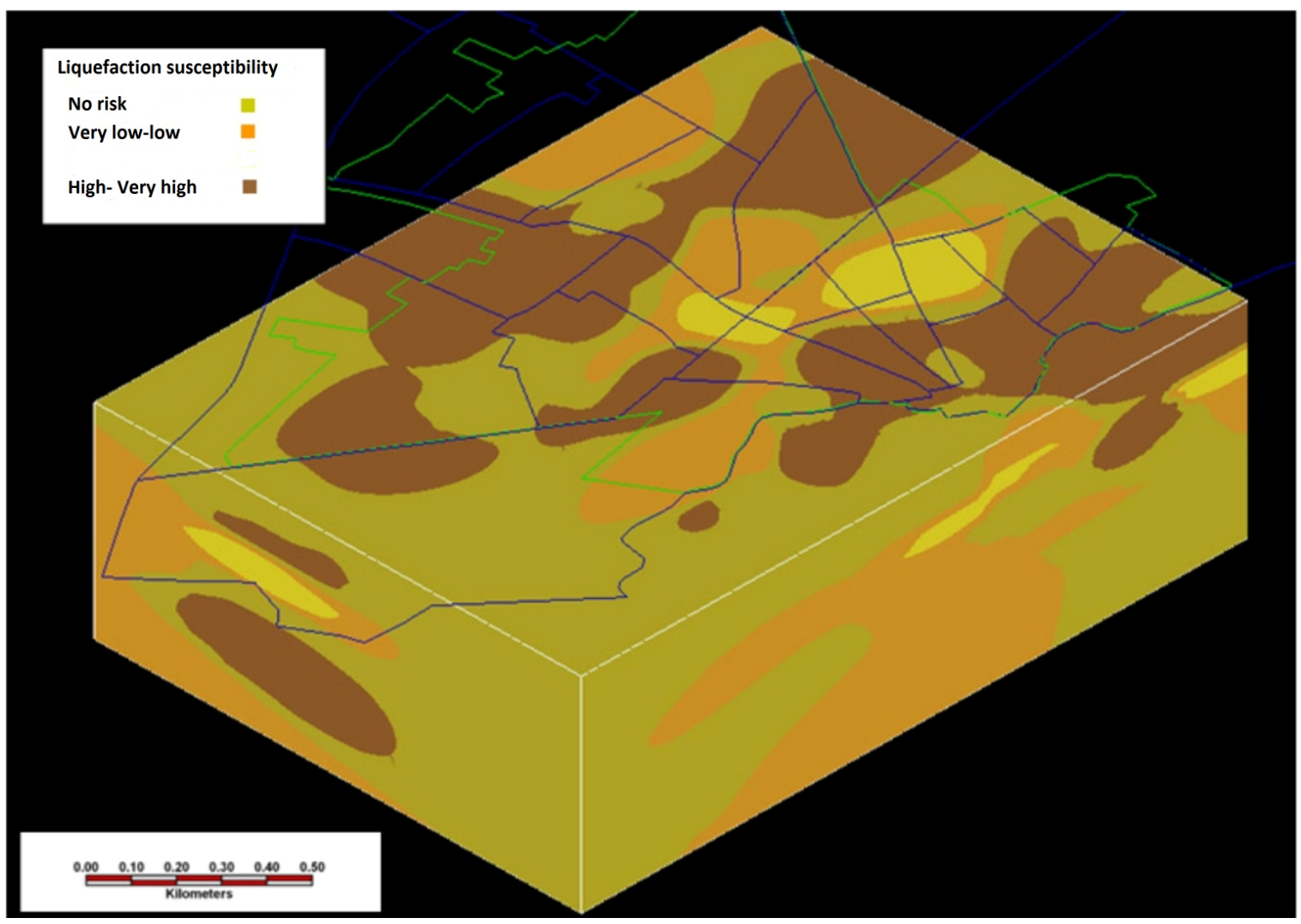

Figure 10: 3D map of liquefaction prone zones. 
signers, engineers and even policymakers to understand the safety precautions necessary to minimize risk in case of a seismic event.

\section{Conclusion}

The purpose of this study was to better understand the city of Eskisehir's geotechnical soil conditions in order to evaluate their vulnerability in case of an earthquake. This pilot study is the first phase of a project that will consider both geotechnical conditions and a liquefaction hazard assessment. By using datasets in a 3D environment, 233 we found that it was possible to capture and interpret 3D subsoil conditions that allowed for spatial analyses of geological architectures and processes at a range of scales. The 3D subsoil conditions can also help engineers during infrastructure construction projects, thereby allowing them to take necessary precautions. This evaluation of subsurface condition uncertainties was much easier than using other 2D techniques. The zone maps that we produced in this study are based on currently available data, knowledge and practice. They can be changed or modified at any time as new data or methods are presented. However, these maps can be useful for defining the steps that are needed to improve existing building codes and to develop new codes, as well as to raise awareness about earthquake hazards among the public, policymakers, land-use planners and local governments.

\section{References}

[1] El May, M., Dlala, M., Bedday, A., Engineering-geological and geotechnical investigation for risk assessment, Cen. Eur. J. Geosci., 2011, 3, 260-270

[2] National Research Council, Geotechnical site investigations for underground projects, V.1, Washington, DC, The National Academy Press, 1984

[3] Thitimakorn, T. Raenak, T., NEHRP site classification and preliminary soil amplification maps of Lamphun City, Northern Thailand, Open Geosciences, 2016, 8, 538-547

[4] Orhan, A. Seyrek, E. Tosun, H., A probabilistic approach for earthquake hazard assessment of the Province of Eskisehir, Turkey, Nat. Hazards Earth Syst. Sci., 2007, 7, 607-614

[5] Ansal, A. Tönük, G. Bayraklı, Y., Microzonation for site conditions for Eskisehir Municipality, Bogazici University, Kandilli Observatory and Earthquake Research Institute, Technical Report, 2005

[6] Yucemen, S., Ozturk, N., and Deniz, A., Probabilistic seismic loss estimation for Eskisehir, Turkey, ECl Conference on Geohazards, Lillehammer, Norway, 18-21 June 2006, 10-18
[7] Mahmoud, A. Shendi, M.M. Pradhan, B. Attia, F., Utilization of remote sensing data and GIS tools for land use sustainability analysis: case study in El-Hammam area, Egypt, Cen. Eur. J. Geosci., 2009,1, 347-367

[8] Iwaniak, A. Kaczmarek, I. Strzelecki, M. Lukowicz, J. Jankowski, P., Enriching and improving the quality of linked data with GIS, Open Geosciences, 2016, v.8, p.323-336

[9] Manakou M, Raptakis D, Chavez-Garcia F, Makra K, Apostolidis P Pitilakis K., Construction of the 3D geological structure of Mygdonian basin (N Greece). In: Proceedings of the fifth international symposium on eastern mediterranean geology, Thessaloniki, Greece, 2004, 14-20

[10] Raptakis, D. Manakou, M. Chávez-García, F.J. Makra, K. Pitilakis, K., 3D configuration of Mygdonian basin and preliminary estimate if its site response, Soil Dynamics and Earthquake Engineering, 2005, 25, 871-887

[11] Yuce, G., Ugurluoglu, D.Y. Adar, N. Yalcin, T. Yaltirak, C. Streil, T. Oeser, V., Monitoring of earthquake precursors by multiparameter stations in Eskisehir region (Turkey), Applied Geochemistry, 2010, 25, 572-579

[12] Koyuncu, N.P. Ulusay, R. 2004. Geo-engineering evaluation with prime consideration to liquefaction potential for Eskisehir City (Turkey), in: Engineering Geology for Infrastructure Planning in Europe Lecture Notes, Pages 125-132

[13] Sarıoglu, F. Emre, O. Dogan, A. Yıldırım, C., Fault zone of Eskisehir and it's earthquake potential, Workshop on Eskisehir Fault Zone and Seismicity of Related Systems, 11-20, 2005

[14] Dahooei, A.H. Afzal, P. Lotfi, M. Jafarirad, A., Identification of mineralized zones in the Zardu area, Kushk SEDEX deposit (Central Iran), based on geological and multifractal modeling, Open Geoscienses, 2016, 8, 143-153

[15] Iyisan, R., Correlations between shear wave velocity and in-situ penetration test results, Technical Journal of Turkish Chamber of Civil Engineers, 1996, 2, 1187-1199

[16] Seed, H.B. Idriss, I. M., Simplified procedure for evaluating liquefaction potential, ASCE, Journal of Soils and Foundations Division, 1971, 97, 1249-1272

[17] Idriss, I.M. Boulanger, R.W., Semi-empirical procedures for evaluating liquefaction potential during earthquakes, Soil Dynamics and Earthquake Engineering, 2006, 26, 115-130

[18] Building Seismic Safety Council, NEHRP (National Earthquake Hazards Reduction Program) Recommended Provisions for Seismic Regulations for New Buildings and Other Structures, Part 1-Part 2, National Institute of Building Sciences, Washington, USA, 2001

[19] ASTM D1586 - 08a.: Standard Test Method for Standard Penetration Test (SPT) and Split-Barrel Sampling of Soils

[20] Bommer,J.J. Acevedo, A.B., The use of real earthquake accelerograms as input to dynamic analysis, Journal of Earthquake Engineering, 2004,8, 1363-2469

[21] Durukal, E., Ansal, A., and Tonuk, G., Effect of ground motion scaling in site response analysis, Proceedings of the $16^{\text {th }}$ International Conference on Soil Mechanics and Geotechnical Engineering 12-15 September 2005, Osaka, Japan

[22] Erdik, M. and Fahjan, Y., Damage scenarios and damage evaluation, Assessing and Managing Earthquake Risk. Geo-scientific and Engineering Knowledge for Earthquake Risk Mitigation, Developments, Tools, Techniques, Geotechnical, Geological, and Earthquake Engineering, Springer, 213-234, 2006 
[23] Macari, E.J. Hoyos, L.R., Earthquake-induced liquefaction potential in western Puerto Rico using GIS technology, The Geological Society of America, Special Paper, 2005, 385, 277-287

[24] Vucetic, M. Dobry, R., Effect of soil plasticity on cyclic response, ASCE, Journal of the Geotechnical Engineering Division, 1991, 117, 89-107

[25] Ordonez, G. A.: SHAKE2000: a computer program for the $1 \mathrm{D}$ analysis of geotechnical earthquake engineering problems user's manual http://www.shake2000.com/
[26] Jha, S. K. and Suzuki, K., Liquefaction potential index considering parameter uncertainties. Engineering Geology, 2009, 107, 55-60

[27] Sonmez, H. and Gokceoglu, C., A liquefaction severity index suggested for engineering practice, Environmental Geology, 2005, 48, 81-91

[28] Iwasaki T., Tokida, K., Tatsuoka, F., Watanabe, S., Yasuda, S., Sato, H., Microzonation for soil liquefaction potential using simplified methods, Proceedings of the $3^{\text {rd }}$ International Conference on Microzonation, June 28 -July 1, 1982, Washington, DC 